\title{
Comparison of Natural Radioactivity of Commonly Used Fertilizer Materials in Egypt and Japan
}

\author{
Nabil M. Hassan, ${ }^{1,2}$ Byung-Uck Chang, ${ }^{1}$ and Shinji Tokonami ${ }^{3}$ \\ ${ }^{1}$ Department of Natural Radiation Safety, Korea Institute of Nuclear Safety, 62 Gwahak-ro, Yuseong-gu, \\ Daejeon 34142, Republic of Korea \\ ${ }^{2}$ Department of Physics, Faculty of Science, Zagazig University, Zagazig 44519, Egypt \\ ${ }^{3}$ Hirosaki University, Institute of Radiation Emergency Medicine, 66-1 Hon-cho, Hirosaki, Aomori, Japan \\ Correspondence should be addressed to Nabil M. Hassan; nmmh1976@zu.edu.eg
}

Received 6 March 2017; Revised 16 May 2017; Accepted 11 June 2017; Published 9 July 2017

Academic Editor: Rafael García-Tenorio

Copyright (C) 2017 Nabil M. Hassan et al. This is an open access article distributed under the Creative Commons Attribution License, which permits unrestricted use, distribution, and reproduction in any medium, provided the original work is properly cited.

Specific activities of ${ }^{238} \mathrm{U},{ }^{232} \mathrm{Th}$, and ${ }^{40} \mathrm{~K}$ in the environment have been redistributed by the use of fertilizers in agriculture so their concentrations in fertilizer materials should be measured to identify the safe utilization of fertilizers. In the present work, the specific activities of these radionuclides in five commonly used fertilizers in Egypt and five fertilizers used in Japan were measured by HPGe and $\gamma$-ray spectrometry. The average values of ${ }^{238} \mathrm{U},{ }^{232} \mathrm{Th}$, and ${ }^{40} \mathrm{~K}$ in Japanese fertilizers were less than their values in Egyptian fertilizers but both had some samples with specific activities greater than the recommended limiting values. The radiological hazards of radium equivalent activity $\left(\mathrm{Ra}_{\mathrm{eq}}\right)$, external $\left(H_{\mathrm{ex}}\right)$ and internal $\left(H_{\text {in }}\right)$ indexes, alpha and gamma indexes, and annual effective dose, due to the presence of these radionuclides, were calculated and compared with each other.

\section{Introduction}

Fertilizers play an important role in the agriculture sector to increase crop yields so fertilizer industries have spread out all over the world. Fertilizers are composed mainly of nitrogen $(\mathrm{N})$, phosphorus $(\mathrm{P})$, and potassium $(\mathrm{K})$, which are essential elements for plants growth. The phosphorus portion is taken from phosphate rocks, which contain a relatively high concentration of naturally occurring ${ }^{238} \mathrm{U},{ }^{232} \mathrm{Th}$, and ${ }^{40} \mathrm{~K}$ and their radioactive daughters $[1,2]$. Therefore, natural radioactivity in soil varies from one location to another due to the extensive use of fertilizer which is the main source of radioactivity in soil other than its natural origin $[3,4]$. The extensive use of fertilizers can increase the amount of radionuclides in soils and in groundwater and consequential ingestion by humans through exposure routes such as drinking water and the food chain $[4,5]$. Once deposited in bone tissue ${ }^{226} \mathrm{Ra}$ has a high potential for causing biological damage because of the continuous irradiation of the human skeleton over many years and it can induce bone sarcoma $[4,5]$.
Factory workers that produce fertilizers and those who use fertilizers in agriculture are exposed to gamma radiation (external exposure) and alpha particles (internal exposure) emitted from the radionuclides of the ${ }^{238} \mathrm{U}$ series, ${ }^{232} \mathrm{Th}$ series, and ${ }^{40} \mathrm{~K}$. External exposure occurs directly by $\gamma$-rays, whereas internal exposure occurs by $\alpha$-particles that result from the inhalation of radon and its progenies. Consequently, the $\alpha$-particle dose is delivered directly to the bronchial tissue, creating a potential for radiogenic lung cancer [6-8]. Therefore, radiation released from fertilizers has a potential of causing cancers in individuals exposed to significant levels so that monitoring of natural radioactivity in fertilizers has an importance from the viewpoint of radiation protection $[9,10]$.

There is a significantly increasing international awareness of radiation hazards of fertilizer materials as a potential source of risk to workers, members of the public, and the environment. Japan as a developed country has a good radiation protection system so that, in the present work, the natural specific activities of ${ }^{238} \mathrm{U},{ }^{232} \mathrm{Th}$, and ${ }^{40} \mathrm{~K}$, in commonly used 
TABLE 1: Activity concentrations of ${ }^{226} \mathrm{Ra},{ }^{232} \mathrm{Th}$, and ${ }^{40} \mathrm{~K}$ in Egyptian fertilizers.

\begin{tabular}{|c|c|c|c|c|c|}
\hline \multirow{2}{*}{ Samples name } & \multirow{2}{*}{ Sample code } & \multirow{2}{*}{ Composition of fertilizer } & \multicolumn{3}{|c|}{ Specific activity $\left(\mathrm{Bq} \mathrm{kg}^{-1}\right)$} \\
\hline & & & ${ }^{226} \mathrm{Ra}$ & ${ }^{232} \mathrm{Th}$ & ${ }^{40} \mathrm{~K}$ \\
\hline Fertilizer 1 & EF-1 & $\operatorname{SSP}\left\{\mathrm{P}_{2} \mathrm{O}_{5}(15 \%)\right\}$ & $761 \pm 31$ & $67 \pm 13$ & $251 \pm 94$ \\
\hline Fertilizer 2 & $\mathrm{EF}-2$ & $\operatorname{SSP}\left\{\mathrm{P}_{2} \mathrm{O}_{5}(12 \%)\right\}$ & $557 \pm 19$ & $15 \pm 6$ & $175 \pm 27$ \\
\hline Fertilizer 3 & EF-3 & $\operatorname{SSP}\left\{\mathrm{P}_{2} \mathrm{O}_{5}(16 \%)\right\}$ & $782 \pm 24$ & $14 \pm 8$ & $222 \pm 24$ \\
\hline Fertilizer 4 & EF-4 & NPK fertilizer & $443 \pm 11$ & ND & $88 \pm 22$ \\
\hline Fertilizer 5 & EF-5 & Triple fertilizer & $312 \pm 14$ & ND & $175 \pm 31$ \\
\hline
\end{tabular}

ND: nondetectable value (the measured value less than thorium detection limit of $3 \mathrm{~Bq} \mathrm{~kg}^{-1}$ ).

TABLE 2: Activity concentrations of ${ }^{226} \mathrm{Ra},{ }^{232} \mathrm{Th}$, and ${ }^{40} \mathrm{~K}$ in Japanese fertilizers.

\begin{tabular}{|c|c|c|c|c|c|}
\hline \multirow{2}{*}{ Samples name } & \multirow{2}{*}{ Sample code } & \multirow{2}{*}{ Composition of fertilizer } & \multicolumn{3}{|c|}{ Specific activity $\left(\mathrm{Bq} \mathrm{kg}^{-1}\right)$} \\
\hline & & & ${ }^{226} \mathrm{Ra}$ & ${ }^{232} \mathrm{Th}$ & ${ }^{40} \mathrm{~K}$ \\
\hline Fertilizer 1 & JF1 & Phosphoric acid $10 \%$ & $25 \pm 1$ & $5 \pm 2$ & $3909 \pm 21$ \\
\hline Fertilizer 2 & JF2 & Phosphoric acid 8\% & $62 \pm 1$ & $15 \pm 1$ & $3280 \pm 17$ \\
\hline Fertilizer 3 & JF3 & Phosphoric acid 20\% & $74 \pm 1$ & $6 \pm 1$ & $48 \pm 2$ \\
\hline Fertilizer 4 & JF4 & Phosphoric acid 20\% & $200 \pm 2$ & $12 \pm 1$ & $231 \pm 4$ \\
\hline Fertilizer 5 & JF5 & Phosphoric acid $17 \%$ & $1264 \pm 5$ & $8 \pm 2$ & $31 \pm 5$ \\
\hline
\end{tabular}

fertilizer materials in Egypt, were measured and their values were compared to those of Japanese fertilizers. In addition, the radiological hazards of radium equivalent activity $\left(\mathrm{Ra}_{\mathrm{eq}}\right)$, external $\left(H_{\mathrm{ex}}\right)$ and internal $\left(H_{\mathrm{in}}\right)$ indexes, alpha and gamma indexes, and annual effective dose, due to the presence of those radionuclides, were calculated and compared with recommended limits.

\section{Materials and Methods}

2.1. Sample Preparation. Samples of five commonly used fertilizers in Egypt and five fertilizers used in Japan as well were collected from different companies and factories, as shown in Tables 1 and 2. The selected samples were crushed and sieved through a $1 \mathrm{~mm}$ mesh size to remove the larger grains size and to become more uniform. Then, these samples were oven dried in a temperature controlled oven at $110^{\circ} \mathrm{C}$ for $24 \mathrm{~h}$ to ensure that the moisture is completely removed. After moisture removal, the samples were cooled down to room temperature in a desiccator.

The dried homogenized samples were packed into airtight polyethylene containers $(6 \mathrm{~cm}$ in diameter and $8 \mathrm{~cm}$ in height). The containers were carefully sealed with adhesive epoxy to prevent ${ }^{222} \mathrm{Rn}$ and ${ }^{220} \mathrm{Rn}$ from escaping. Each sample was stored in its sealed container for four weeks to achieve radioactive secular equilibrium. A similarly sealed empty container of the same geometry was left for the same time period in order to measure the radionuclide background [15].

2.2. Measurement of Radionuclide Activities with $\gamma$-Ray Spectrometry. Specific activities of ${ }^{226} \mathrm{Ra},{ }^{232} \mathrm{Th}$, and ${ }^{40} \mathrm{~K}$ in the samples were measured using an HPGe detector, ORTEC (model: GMX-70230 EG\&G) with a volume of $190 \mathrm{~cm}^{3}$, a measured efficiency of $70 \%$, and an energy resolution of
$2.3 \mathrm{keV}$ at $1332.5 \mathrm{keV}$. This was connected to a personal computer with a data acquisition system that has a Multichannel analyzer, model CANBERRA Multi Port II (4,096 channels). The data analysis was carried out via an APTEC MCA software program.

The HPGe detector's peak efficiency was determined using standard point sources of ${ }^{60} \mathrm{Co},{ }^{133} \mathrm{Ba},{ }^{137} \mathrm{Cs},{ }^{22} \mathrm{Na}$, and a standard source of ${ }^{226} \mathrm{Ra}$, maintained in the same container geometry as that used for the samples. Since radium $\left({ }^{226} \mathrm{Ra}\right)$ and its progenies produce $98.5 \%$ of the radiological effects of the uranium series, the activities of ${ }^{238} \mathrm{U}$ and the precursors of ${ }^{226} \mathrm{Ra}$ are normally ignored. Therefore, the reference for the ${ }^{238} \mathrm{U}$ series is often ${ }^{226} \mathrm{Ra}$ instead of ${ }^{238} \mathrm{U}$ [15]. The ${ }^{226} \mathrm{Ra}$ activity was deduced from the $\gamma$-rays of energies of $351.9 \mathrm{keV}$ associated with the decay of ${ }^{214} \mathrm{~Pb}$ and $609.3 \mathrm{keV} \gamma$-rays associated with the decay of ${ }^{214} \mathrm{Bi}$. The $186 \mathrm{keV}$ photon peak of ${ }^{226} \mathrm{Ra}$ was not used because of the interfering peak of ${ }^{235} \mathrm{U}$ with energy of $185.7 \mathrm{keV}$. The ${ }^{232} \mathrm{Th}$ concentration was estimated from the $\gamma$-rays of energies of $911.1 \mathrm{keV}$ associated with the decay of ${ }^{228} \mathrm{Ac}$ and the $583.4 \mathrm{keV}$ line associated with the decay of ${ }^{208} \mathrm{Tl}$. The ${ }^{40} \mathrm{~K}$ concentration was obtained from $1460.8 \mathrm{keV} \gamma$-rays from the decay of ${ }^{40} \mathrm{~K}$ itself [16-21]. The specific activity concentration $\left(\mathrm{Bq} \mathrm{kg}^{-1}\right)$ of those radionuclides was calculated from (1) [15]. For the calculations of specific radioactivity, coincidence-summing and self-absorption correction factors have not been applied.

$$
A=\frac{C}{p w t \varepsilon},
$$

where $C$ is the net counts above the background, $p$ is the absolute emission probability of the $\gamma$-ray decay, $w$ is the net dry sample weight $(\mathrm{kg}), t$ is the measurement time (s), and $\varepsilon$ is the absolute efficiency of the detector. 


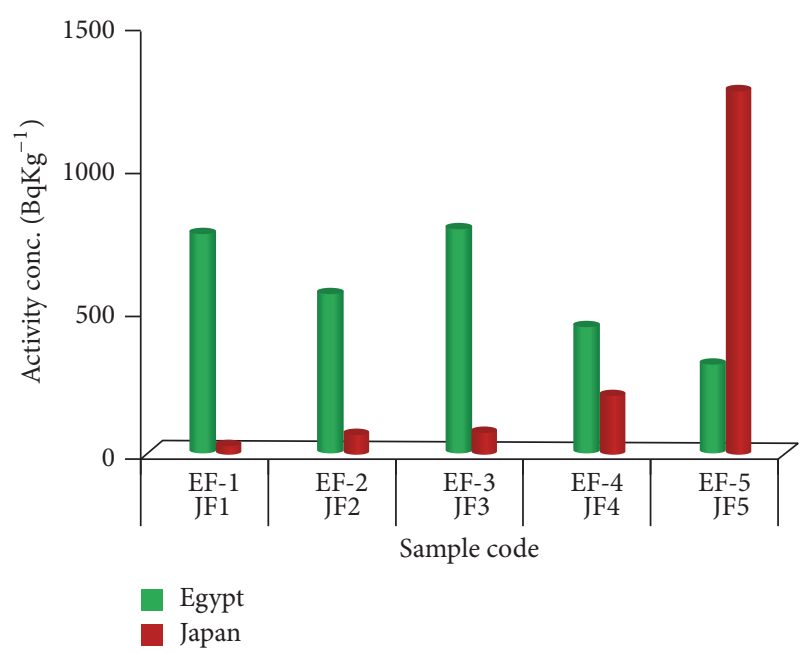

(a) $\mathrm{Ra}^{226}$ activity

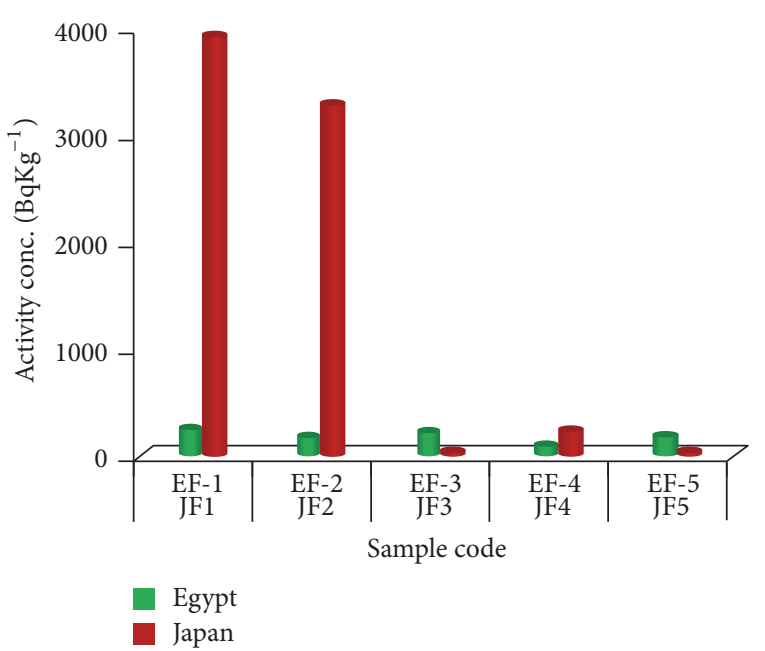

(c) $\mathrm{K}^{40}$ activity

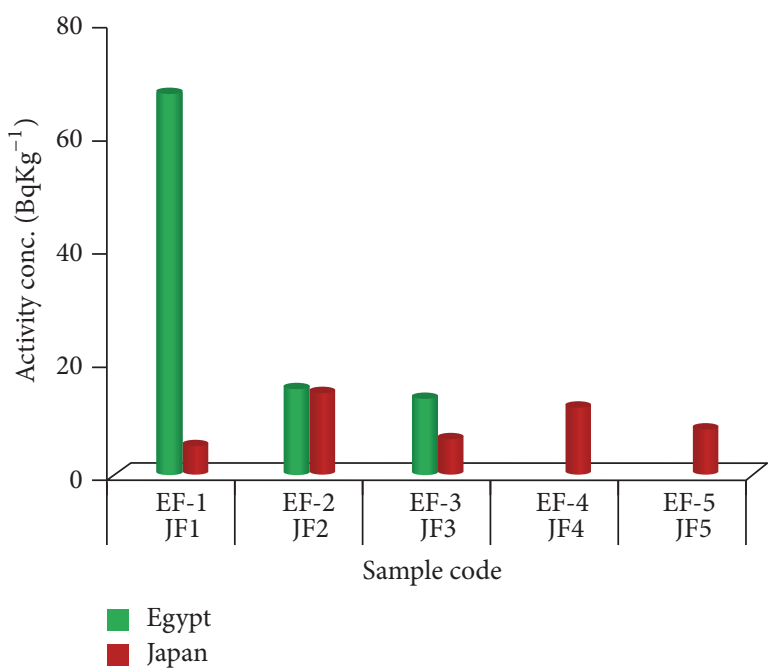

(b) $\mathrm{Th}^{232}$ activity

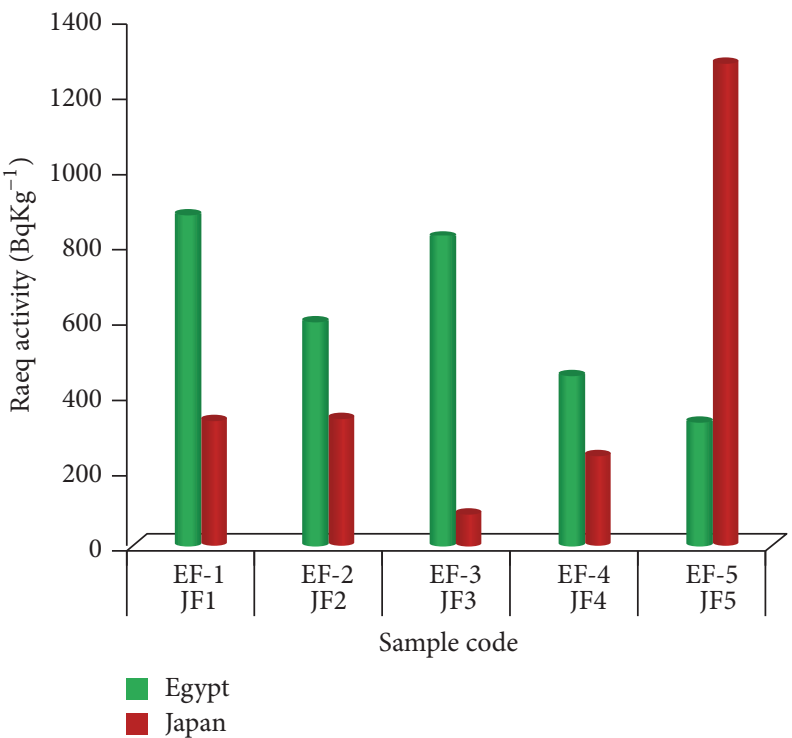

(d) $\mathrm{Ra}_{\text {eq }}$ activity

FIGURE 1: Comparison of natural radioactivities and radium equivalent of Egyptian and Japanese fertilizers.

\section{Results and Discussion}

The specific activities of ${ }^{226} \mathrm{Ra},{ }^{232} \mathrm{Th}$, and ${ }^{40} \mathrm{~K}$ in commonly used fertilizer samples in Egypt and Japan are given in Tables 1 and 2. The respective average radionuclide activities of ${ }^{226} \mathrm{Ra}$, ${ }^{232} \mathrm{Th}$, and ${ }^{40} \mathrm{~K}$ in the Egyptian fertilizer samples were $571 \pm$ $20 \mathrm{~Bq} \mathrm{~kg}^{-1}, 19 \pm 5 \mathrm{~Bq} \mathrm{~kg}^{-1}$, and $182 \pm 40 \mathrm{~Bq} \mathrm{~kg}^{-1}$ while, for the Japanese fertilizers, they were $325 \pm 2 \mathrm{~Bq} \mathrm{~kg}^{-1}, 9 \pm 1 \mathrm{~Bq} \mathrm{~kg}^{-1}$, and $1500 \pm 10 \mathrm{~Bq} \mathrm{~kg}^{-1}$, as shown in Figure 1 and Tables 1 and 2. The radionuclide concentrations in Japanese fertilizer were less than those of Egyptian fertilizers except for potassium, as seen in Figure 1. The radionuclide concentration of ${ }^{40} \mathrm{~K}$ is much higher in Japanese fertilizer samples and especially sample JF-1. Both Egyptian and Japanese fertilizers maintain radionuclide concentrations less than the recommended limits by UNSCEAR, 2008, [22].
To compare the radiation effect of different radionuclides in a sample UNSCEAR $[22,23]$ has introduced the radium equivalent concentration $\left(\mathrm{Ra}_{\mathrm{eq}}\right)$.

$$
\mathrm{Ra}_{\mathrm{eq}}=A_{\mathrm{Ra}}+1.43 A_{\mathrm{Th}}+0.077 A_{\mathrm{K}},
$$

where $A_{\mathrm{Ra}}, A_{\mathrm{Th}}$, and $A_{\mathrm{K}}$ are activities of ${ }^{226} \mathrm{Ra},{ }^{232} \mathrm{Th}$, and ${ }^{40} \mathrm{~K}$, respectively, in $\mathrm{Bq} \mathrm{kg}^{-1}$. Radium equivalent concentration was calculated based on the estimation that $370 \mathrm{~Bq} \mathrm{~kg}^{-1}$ of ${ }^{226} \mathrm{Ra}, 259 \mathrm{~Bq} \mathrm{~kg}^{-1}$ of ${ }^{232} \mathrm{Th}$, and $4810 \mathrm{~Bq} \mathrm{~kg}^{-1}$ of ${ }^{40} \mathrm{~K}_{\text {produce }}$ the same equivalent $\gamma$-ray dose. The value of $\mathrm{Ra}_{\text {eq }}$ of fertilizer must be less than $370 \mathrm{~Bq} \mathrm{~kg}^{-1}$ to keep $\gamma$-ray dose below $1.5 \mathrm{mSv} \mathrm{y}^{-1}$. The average radium equivalent concentration in Egyptian fertilizer was $613 \pm 33 \mathrm{~Bq} \mathrm{~kg}^{-1}$ while for Japanese fertilizer, it was $454 \pm 5 \mathrm{~Bq} \mathrm{~kg}^{-1}$, as shown in Tables 3 and 4 . All Japanese fertilizers have radium equivalent concentrations 




(a) External hazard index

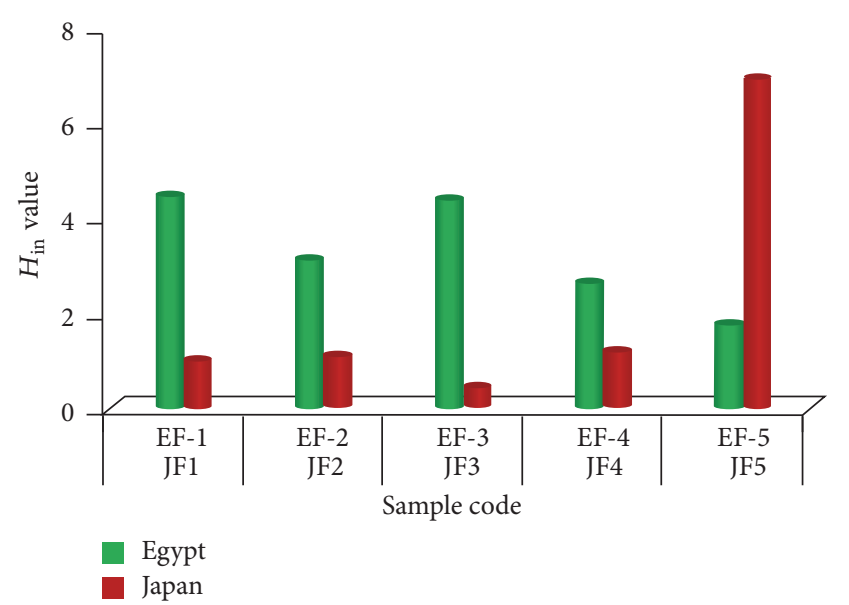

(b) Internal hazard index

FIgURE 2: Comparison of external and internal indexes of Egyptian and Japanese fertilizers.

TABLE 3: The Radium equivalent and hazard index in Egyptian fertilizers.

\begin{tabular}{lccc}
\hline $\begin{array}{l}\text { Sample } \\
\text { code }\end{array}$ & $\begin{array}{c}\text { Radium equivalent } \\
\mathrm{Ra}_{\mathrm{eq}},\left(\mathrm{Bq} \mathrm{kg}^{-1}\right)\end{array}$ & $\begin{array}{c}\text { External hazard } \\
\text { index }\left(H_{\mathrm{ex}}\right)\end{array}$ & $\begin{array}{c}\text { Internal hazard } \\
\text { index }\left(H_{\text {in }}\right)\end{array}$ \\
\hline EF-1 & $877 \pm 57$ & $2.37 \pm 0.08$ & $4.43 \pm 0.24$ \\
EF-2 & $592 \pm 43$ & $1.60 \pm 0.05$ & $3.11 \pm 0.17$ \\
EF-3 & $819 \pm 37$ & $2.21 \pm 0.06$ & $4.33 \pm 0.17$ \\
EF-4 & $449 \pm 13$ & $1.21 \pm 0.03$ & $2.41 \pm 0.07$ \\
EF-5 & $326 \pm 16$ & $0.88 \pm 0.01$ & $1.72 \pm 0.08$ \\
\hline
\end{tabular}

less than the recommended limit except JF5 (1277 $\left.\pm 8 \mathrm{~Bq} \mathrm{~kg}^{-1}\right)$ while all Egyptian fertilizer samples have radium equivalent concentrations greater than recommended limit except EF5 $\left(326 \pm 16 \mathrm{~Bq} \mathrm{~kg}^{-1}\right)$, as seen in Figure 1 .

The external hazard index $\left(H_{\mathrm{ex}}\right)$ was determined from (3) $[24,25]:$

$$
H_{\mathrm{ex}}=\frac{A_{\mathrm{Ra}}}{370}+\frac{A_{\mathrm{Th}}}{259}+\frac{A_{\mathrm{K}}}{4810}
$$

where $A_{\mathrm{Ra}}, A_{\mathrm{Th}}$, and $A_{\mathrm{K}}$ are the activities of ${ }^{226} \mathrm{Ra},{ }^{232} \mathrm{Th}$, and ${ }^{40} \mathrm{~K}$, respectively, in $\mathrm{Bq} \mathrm{kg}^{-1}$. The external hazard index should be less than unity in order to keep $\gamma$-radiation dose less than $1.5 \mathrm{mSvy}^{-1}$. The calculated external hazard index for Egyptian fertilizers had an average of $1.65 \pm 0.04$ (Table 3) while it was $1.22 \pm 0.06$ for Japanese fertilizer samples (Table 4). The external hazard index for Japanese fertilizers was less than the recommended limit except for the sample of JF5 $(3.45 \pm 0.09)$ while its value was higher than the recommended limit for Egyptian fertilizers except the one sample of EF-5 (0.88 \pm 0.01$)$, as shown in Figure 2(a). In addition to the external hazard, radon and its shortlived products are also hazardous to respiratory organs. The internal exposure to radon and its progeny produced is quantified by an internal hazard index $\left(H_{\text {in }}\right)$ which can be defined as $[24,25]$

$$
H_{\text {in }}=\frac{A_{\mathrm{Ra}}}{185}+\frac{A_{\mathrm{Th}}}{259}+\frac{A_{\mathrm{K}}}{4810} .
$$

For the safe use of a material, $H_{\text {in }}$ should be less than unity. The average value of the internal hazard index was $3.20 \pm 0.15$ (Table 3 and Figure 2(b)) for Egyptian fertilizers, all of which are higher than the recommended limit. This means that the use of Egyptian fertilizers should be subject to precautions. On the other hand, Japanese fertilizers had a mean internal hazard index of $2.11 \pm 0.13$, with JF-1 and JF-3 having internal hazard index less than unity (Table 4 and Figure 2(b)).

The use of fertilizers in agriculture is a possible source of exposure for the public. Elevated radionuclides exposure of the public might be expected, for example, to the workers in sites being developed for housing. [22]. The absorbed dose $(D)$ due to $\gamma$-rays emitted at $1 \mathrm{~m}$ of air above ground can be calculated from the following equation [24]:

$$
D\left(\mathrm{nGy} \mathrm{h}^{-1}\right)=0.462 A_{\mathrm{Ra}}+0.621 A_{\mathrm{Th}}+0.042 A_{\mathrm{K}} .
$$

The absorbed dose was calculated for the samples as shown in Tables 5 and 6 and Figure 3(a). The radiation absorbed dose was varied from $141 \pm 7 \mathrm{nGyh}^{-1}$ (EF5) to $380 \pm$ $26 \mathrm{nGyh}^{-1}$ (EF1) with a mean value of $264 \pm 15 \mathrm{nGyh}^{-1}$ for Egyptian fertilizers. For Japanese fertilizers it varied from $38 \pm 1 \mathrm{nGyh}^{-1}$ (JF3) to $546 \pm 4 \mathrm{nGyh}^{-1}$ (JF5) with a mean value of $210 \pm 2 \mathrm{nGyh}^{-1}$. All Egyptian fertilizers had absorbed radiation dose values greater than the limit recommended by UNSCEAR [23], of $59 \mathrm{nGyh}^{-1}$ as also Japanese fertilizers except JF3, as given in Tables 5 and 6 and Figure 3(a). Therefore, except for one sample, all the Egyptian and Japanese fertilizers gave an absorbed dose larger than recommended so that these materials should be used with precautions. 


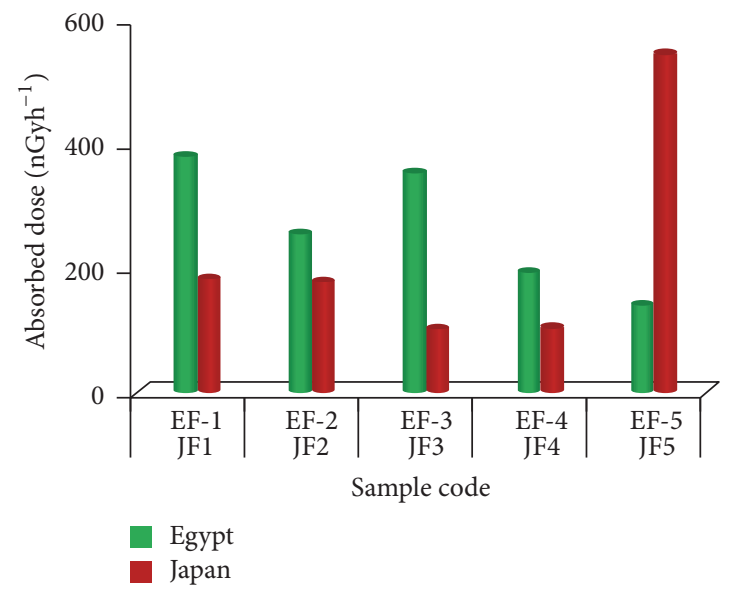

(a) Absorbed dose

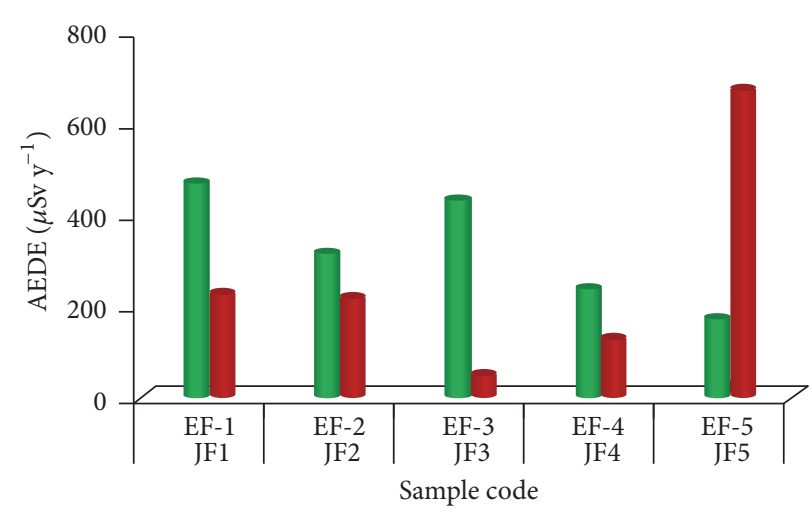

Egypt

Japan

FIGURE 3: Comparison of absorbed and annual effective doses of Egyptian and Japanese fertilizers.

TABLE 4: The Radium equivalent and hazard index in Japanese fertilizers.

\begin{tabular}{lccr}
\hline Sample code & Radium equivalent $\mathrm{Ra}_{\text {eq }},\left(\mathrm{Bq} \mathrm{kg}^{-1}\right)$ & External hazard index $\left(H_{\mathrm{ex}}\right)$ & Internal hazard index $\left(H_{\text {in }}\right)$ \\
\hline JF1 & $333 \pm 5$ & $0.90 \pm 0.05$ & $0.97 \pm 0.10$ \\
JF2 & $336 \pm 5$ & $0.91 \pm 0.08$ & $1.07 \pm 0.11$ \\
JF3 & $87 \pm 2$ & $0.23 \pm 0.03$ & $0.43 \pm 0.06$ \\
JF4 & $235 \pm 3$ & $0.63 \pm 0.04$ & $1.18 \pm 0.09$ \\
JF5 & $1277 \pm 8$ & $3.45 \pm 0.09$ & $6.87 \pm 0.28$ \\
\hline
\end{tabular}

TABLE 5: Absorbed and annual effective dose and hazard indexes of fertilizers used in Egypt.

\begin{tabular}{|c|c|c|c|c|}
\hline Sample code & Absorbed dose $\left(\mathrm{nGy} \mathrm{h}^{-1}\right)$ & Annual effective dose $\left(\mu \mathrm{Sv}^{-1}\right)$ & Gamma index & Alpha index \\
\hline EF-1 & $380 \pm 26$ & $468 \pm 3$ & $2.96 \pm 0.20$ & $3.81 \pm 0.16$ \\
\hline $\mathrm{EF}-2$ & $255 \pm 20$ & $314 \pm 2$ & $1.99 \pm 0.10$ & $2.79 \pm 0.09$ \\
\hline EF-3 & $353 \pm 17$ & $434 \pm 2$ & $2.75 \pm 0.13$ & $3.91 \pm 0.12$ \\
\hline EF-4 & $193 \pm 6$ & $237 \pm 1$ & $1.50 \pm 0.04$ & $2.21 \pm 0.06$ \\
\hline EF-5 & $141 \pm 7$ & $173 \pm 1$ & $1.10 \pm 0.06$ & $1.56 \pm 0.07$ \\
\hline
\end{tabular}

TABLE 6: Absorbed and annual effective dose and hazard indexes of fertilizers used in Japan.

\begin{tabular}{lcccc}
\hline Sample code & Absorbed dose $\left(\mathrm{nGy} \mathrm{h}^{-1}\right)$ & Annual effective dose $\left(\mu \mathrm{Sv} \mathrm{y}^{-1}\right)$ & Gamma index & Alpha index \\
\hline JF1 & $182 \pm 3$ & $225 \pm 3$ & $1.41 \pm 0.07$ & $0.13 \pm 0.03$ \\
JF2 & $177 \pm 2$ & $218 \pm 3$ & $1.37 \pm 0.05$ & $0.31 \pm 0.05$ \\
JF3 & $38 \pm 1$ & $47 \pm 1$ & $0.29 \pm 0.03$ & $0.37 \pm 0.07$ \\
JF4 & $103 \pm 2$ & $127 \pm 2$ & $0.80 \pm 0.04$ & $1.00 \pm 0.11$ \\
JF5 & $546 \pm 4$ & $672 \pm 4$ & $4.26 \pm 0.19$ \\
\hline
\end{tabular}

The annual effective dose $(E)$ from $\gamma$-rays emitted from ${ }^{226} \mathrm{Ra},{ }^{232} \mathrm{Th}$ and ${ }^{40} \mathrm{k}$ in the samples was calculated from [22]

$$
\begin{aligned}
E= & D\left(\mathrm{nGy} \mathrm{h}^{-1}\right) \times 8760\left(\mathrm{hy}^{-1}\right) \times O \\
& \times C(\mathrm{mSv} / \mathrm{nGy}),
\end{aligned}
$$

where $O$ is the occupancy factor and $C$ is the absorbed to effective dose conversion factor of $0.7 \times 10^{-6} \mathrm{~Sv}$ per Gy. The annual effective doses from $\gamma$-rays emitted by ${ }^{226} \mathrm{Ra},{ }^{232} \mathrm{Th}$ and ${ }^{40} \mathrm{k}$ in the samples varied from $173 \pm 1 \mu \mathrm{Svy}^{-1}$ (EF5) to
$468 \pm 3 \mu \mathrm{Sv}^{-1}$ (EF1) with a mean value of $325 \pm 2 \mu \mathrm{Sv} \mathrm{y}^{-1}$ for the Egyptian samples. For Japanese samples they varied from $47 \pm 1 \mu \mathrm{Sv} \mathrm{y}^{-1}$ (JF3) to $672 \pm 4 \mu \mathrm{Sv} \mathrm{y}^{-1}$ (JF5) with a mean value of $258 \pm 3 \mu \mathrm{Sv} \mathrm{y}^{-1}$, as shown in Tables 5 and 6 and Figure 3(b). The annual effective dose of all studied samples of Egyptian and Japanese fertilizers is less than the recommended limiting value of $480 \mu \mathrm{Sv} \mathrm{y}^{-1}$ [22] except for the sample JF5.

The $\gamma$-ray radiation hazards associated with the natural radionuclides in fertilizer materials can be assessed by means of the radioactivity level index, $I_{\gamma}$. According to the European 


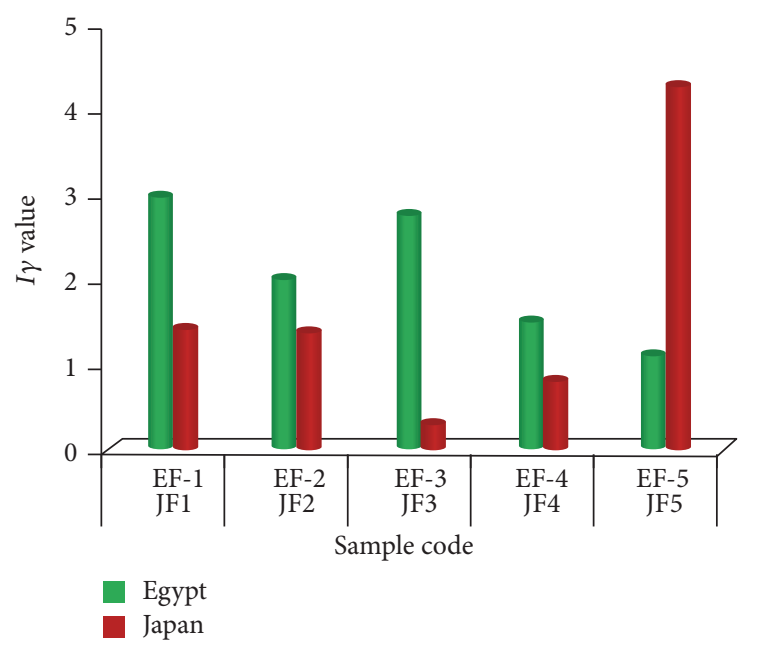

(a) Gamma index

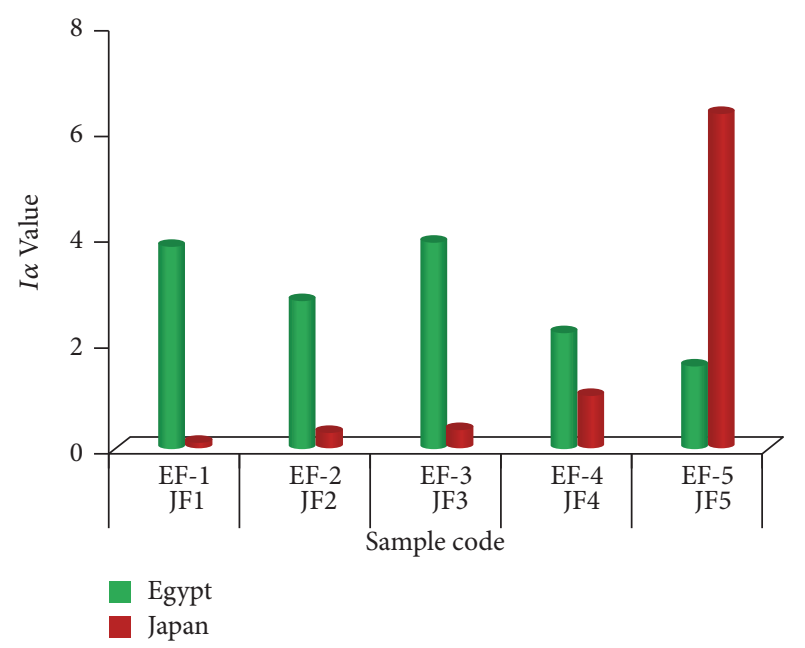

(b) Alpha index

FIGURE 4: Comparison of gamma and alpha indexes of Egyptian and Japanese fertilizers.

TABLE 7: Comparison of radiological indexes in the present work and their values in literature.

\begin{tabular}{lcccc}
\hline Country & Sample & Radium equivalent $(\mathrm{Bq} / \mathrm{kg})$ & Gamma index $\left(I_{\gamma}\right)$ & References \\
\hline Egypt & Fertilizer & $613 \pm 33$ & $2.06 \pm 0.11$ & $1.63 \pm 0.08$ \\
Japan & Fertilizer & $454 \pm 5$ & 9.6 & Present work \\
Algeria & NPK fertilizer & 1168 & 12.3 & Present work \\
Brazil & NPK fertilizer & 1772 & - & {$[3]$} \\
Saudi Arabia & NPK fertilizer & 275 & 3.1 & {$[11]$} \\
Egypt (Qena) & Phosphate fertilizer & 462 & - & {$[12]$} \\
Bangladesh & Triple superphosphate & 374 & {$[14]$} \\
\hline
\end{tabular}

Commission guidelines, $I_{\gamma}$ should be less than $6\left(2<I_{\gamma}<6\right)$ for a radiation dose of $1 \mathrm{mSv} \mathrm{y}^{-1}[26]$. The $\gamma$-ray index $\left(I_{\gamma}\right)$ can be calculated from [26]

$$
I_{\gamma}=\frac{C_{\mathrm{Ra}}}{300}+\frac{C_{\mathrm{Th}}}{200}+\frac{C_{\mathrm{K}}}{3000} .
$$

$I_{\gamma}$ of the Egyptian samples varied from $1.10 \pm 0.06$ for (EF-5) to $2.96 \pm 0.20$ for (EF-1) with a mean value of $2.06 \pm 0.11$. For the Japanese samples, it varied from $0.29 \pm 0.03$ for (JF3) to $4.26 \pm 0.19$ for (JF5) with a mean value of $1.63 \pm 0.08$, as can be seen in Tables 5 and 6 and Figure 4(a). All the measured samples had a radioactivity level index less than 6 , so any of these samples can be used without special precautions [26].

Alpha radiation due to the released radon from samples is called alpha index $\left(I_{\alpha}\right)$ which can be calculated from (8), [26]. Alpha index should be less than unity to reflect a radium concentration value less than $200 \mathrm{~Bq} \mathrm{~kg}^{-1}$ (the upper recommended value) which leads to a released radon concentration less than $200 \mathrm{~Bq} \mathrm{~m}^{-3}$.

$$
I_{\alpha}=\frac{A_{\mathrm{Ra}}}{200} .
$$

Alpha index of the Egyptian samples varied from $1.56 \pm$ 0.07 (EF5) to $3.91 \pm 0.12$ (EF3) with a mean value of $2.86 \pm$ 0.10 . For Japanese samples, it varied from $0.13 \pm 0.03$ (JF1) to
$6.32 \pm 0.25$ (JF5) with a mean value of $1.63 \pm 0.11$, as seen in Tables 5 and 6 and Figure 4(b). The values of alpha index for Egyptian fertilizers were more than unity while, for Japanese samples, it was less than unity except a sample of JF5.

All these radiological indexes were actually initially developed and established for construction materials but they were used during this study and other previous studies in literature [11-14] to show how much the workers and public could receive radiation dose from fertilizer materials. Table 7 shows a comparison of the estimated radiological indexes values during this work and their values in previous studies in literature. Radium equivalent in the present work was less than its value for fertilizer used in Algeria and Brazil but it was greater than its value for fertilizer used in Saudi Arabia and Bangladesh. Gamma index behaved the trend as radium equivalent, as seen in Table 7.

\section{Conclusion}

Natural radioactivity of ${ }^{226} \mathrm{Ra},{ }^{232} \mathrm{Th}$, and ${ }^{40} \mathrm{~K}$ in different types of fertilizers used in Egypt and in Japan was measured using a high purity germanium detector. The specific activities in Egyptian samples ranged from $312 \pm 14$ to $782 \pm$ $24 \mathrm{~Bq} \mathrm{~kg}^{-1}$ for ${ }^{226} \mathrm{Ra}$, ND to $67 \pm 13 \mathrm{~Bq} \mathrm{~kg}^{-1}$ for ${ }^{232} \mathrm{Th}$, and $88 \pm 22$ to $251 \pm 94 \mathrm{~Bq} \mathrm{~kg}^{-1}$ for ${ }^{40} \mathrm{~K}$. In Japanese samples these 
specific activities ranged from $25 \pm 1$ to $1265 \pm 5 \mathrm{~Bq} \mathrm{~kg}^{-1}$ for ${ }^{226} \mathrm{Ra}, 5 \pm 2$ to $15 \pm 1 \mathrm{~Bq} \mathrm{~kg}^{-1}$ for ${ }^{232} \mathrm{Th}$, and $31 \pm 5$ to $3909 \pm$ $21 \mathrm{~Bq} \mathrm{~kg}^{-1}$ for ${ }^{40} \mathrm{~K}$. The specific radioactivities of Egyptian fertilizers are much higher than their values for Japanese fertilizers but still in the range of recommended limits of UNSCEAR 2008. The radiological hazard indexes, of radium equivalent activities $\left(\mathrm{Ra}_{\mathrm{eq}}\right)$, external and internal indexes, gamma index, absorbed radiation, and annual effective doses of the Egyptian fertilizers were higher than the values for Japanese fertilizers and higher than the respective safely values of $370 \mathrm{~Bq} \mathrm{~kg}^{-1}$, unity, $59 \mathrm{nGy} \mathrm{h}^{-1}$, and $480 \mu \mathrm{Sv} \mathrm{y}^{-1}$. From all of these results, we deduce that the amount of fertilizers that showed high radioactivities should be decreased and used with precautions.

\section{Conflicts of Interest}

The authors declared that there are no conflicts of interest regarding the publication of this paper.

\section{Acknowledgments}

The authors would like to express their thanks and appreciation to Zagazig University and the Egyptian Nuclear Research Centre, EAEA, Egypt, for giving them the opportunity to carry out this work in their laboratories. The authors also thank Dr. K. Iwaoka and Dr. M. Hosoda, Institute of Radiation Emergency Medicine, Hirosaki University, Japan, for helping them in collecting the samples.

\section{References}

[1] N. N. Jibiri and K. P. Fasae, "Activity concentrations of ${ }^{226} \mathrm{Ra}$, ${ }^{232} \mathrm{Th}$ and ${ }^{40} \mathrm{~K}$ in brands of fertilisers used in Nigeria," Radiation Protection Dosimetry, vol. 148, no. 1, pp. 132-137, 2012.

[2] N. M. Hassan, N. A. Mansour, M. Fayez-Hassan, and E. Sedqy, "Assessment of natural radioactivity in fertilizers and phosphate ores in Egypt," Journal of Taibah University for Science, vol. 10, no. 2, pp. 296-306, 2016.

[3] W. Boukhenfouf and A. Boucenna, "The radioactivity measurements in soils and fertilizers using gamma spectrometry technique," Journal of Environmental Radioactivity, vol. 102, no. 4, pp. 336-339, 2011.

[4] S. Righi, P. Lucialli, and L. Bruzzi, "Health and environmental impacts of a fertilizer plant-Part I: assessment of radioactive pollution," Journal of Environmental Radioactivity, vol. 82, no. 2, pp. 167-182, 2005.

[5] G. Marović and J. Senčar, "226Ra and possible water contamination due to phosphate fertilizer production," Journal of Radioanalytical and Nuclear Chemistry Letters, vol. 200, no. 1, pp. 9-18, 1995.

[6] N. M. Hassan, N. A. Mansour, M. Fayez-Hassan, and S. Fares, "Assessment of radiation hazards due to exposure to radionuclides in marble and ceramic commonly used as decorative building materials in Egypt," Indoor and Built Environment, vol. 26, no. 3, pp. 317-326, 2017.

[7] K. Iwaoka, H. Tabe, and H. Yonehara, "Natural radioactivity of bedrock bath instruments and hot spring instruments in Japan," Journal of Radioanalytical and Nuclear Chemistry, vol. 295, no. 2, pp. 817-821, 2013.
[8] N. M. Hassan, "Radon emanation coefficient and its exhalation rate of wasted petroleum samples associated with petroleum industry in Egypt," Journal of Radioanalytical and Nuclear Chemistry, vol. 299, no. 1, pp. 111-117, 2014.

[9] N. M. Hassan, M. Hosoda, T. Ishikawa et al., "Radon migration process and its influence factors; review," Japanese Journal of Health Physics, vol. 44, no. 2, pp. 218-231, 2009.

[10] W. W. Nazaroff, "Radon transport from soil to air," Reviews of Geophysics, vol. 30, no. 2, pp. 137-160, 1992.

[11] V. A. Becegato, F. J. F. Ferreira, and W. C. P. Machado, "Concentration of radioactive elements ( $\mathrm{U}$, Th and $\mathrm{K})$ derived from phosphatic fertilizers in cultivated soils," Brazilian Archives of Biology and Technology, vol. 51, no. 6, pp. 1255-1266, 2008.

[12] W. R. Alharbi, "Natural radioactivity and dose assessment for brands of chemical and organic fertilizers used in Saudi Arabia," Journal of Modern Physics, vol. 4, no. 3, pp. 344-348, 2013.

[13] N. K. Ahmed and A. G. M. El-Arabi, "Natural radioactivity in farm soil and phosphate fertilizer and its environmental implications in Qena governorate, Upper Egypt," Journal of Environmental Radioactivity, vol. 84, no. 1, pp. 51-64, 2005.

[14] M. N. Alam, M. I. Chowdhury, M. Kamal, S. Ghose, H. Banu, and D. Chakraborty, "Radioactivity in chemical fertilizers used in Bangladesh," Applied Radiation and Isotopes, vol. 48, no. 8, pp. 1165-1168, 1997.

[15] I. P. Farai and J. A. Ademola, "Radium equivalent activity concentrations in concrete building blocks in eight cities in Southwestern Nigeria," Journal of Environmental Radioactivity, vol. 79, no. 2, pp. 119-125, 2005.

[16] M. Rafique, H. Rehman, M. Matiullah et al., "Assessment of radiological hazards due to soil and building materials used in Mirpur Azad Kashmir; Pakistan," Iranian Journal of Radiation Research, vol. 9, no. 2, pp. 77-87, 2011.

[17] F. Michael, Y. Parpottas, and H. Tsertos, "Gamma radiation measurements and dose rates in commonly used building materials in Cyprus," Radiation Protection Dosimetry, vol. 142, no. 2-4, pp. 282-291, 2010.

[18] J. A. Ademola, "Determination of natural radionuclides content in some building materials in Nigeria by gamma-ray spectrometry," Health Physics, vol. 94, no. 1, pp. 43-48, 2008.

[19] H. Papaefthymiou and O. Gouseti, "Natural radioactivity and associated radiation hazards in building materials used in Peloponnese, Greece," Radiation Measurements, vol. 43, no. 8, pp. 1453-1457, 2008.

[20] M. S. Yasir, A. Ab Majid, and R. Yahaya, "Study of natural radionuclides and its radiation hazard index in Malaysian building materials," Journal of Radioanalytical and Nuclear Chemistry, vol. 273, no. 3, pp. 539-541, 2007.

[21] M. Ngachin, M. Garavaglia, C. Giovani, M. G. Kwato Njock, and A. Nourreddine, "Assessment of natural radioactivity and associated radiation hazards in some Cameroonian building materials," Radiation Measurements, vol. 42, no. 1, pp. 61-67, 2007.

[22] United Nations Scientific Committee on the Effects of Atomic Radiation (UNSCEAR), "United Nations Scientific Committee on the Effects of Atomic Radiation," UNSCEAR Report to the General Assembly, 2008.

[23] United Nations Scientific Committee on the Effects of Atomic Radiation (UNSCEAR), "United Nations Scientific Committee on the Effects of Atomic Radiation," UNSCEAR Report to the General Assembly, 2000. 
[24] Sabiha-Javied, M. Tufail, and M. Asghar, "Hazard of NORM from phosphorite of Pakistan," Journal of Hazardous Materials, vol. 176, no. 1-3, pp. 426-433, 2010.

[25] N. M. Hassan, N. A. Mansour, and M. Fayez-Hassan, "Evaluation of radionuclide concentrations and associated radiological hazard indexes in building materials used in Egypt," Radiation Protection Dosimetry, vol. 157, no. 2, pp. 214-220, 2013.

[26] K. Khan, H. M. Khan, M. Tufail, A. J. A. H. Khatibeh, and N. Ahmad, "Radiometric analysis of Hazara phosphate rock and fertilizers in Pakistan," Journal of Environmental Radioactivity, vol. 38, no. 1, pp. 77-84, 1998. 

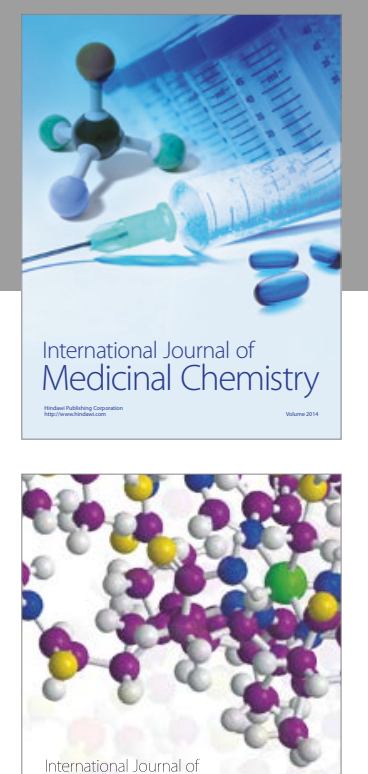

Carbohydrate Chemistry

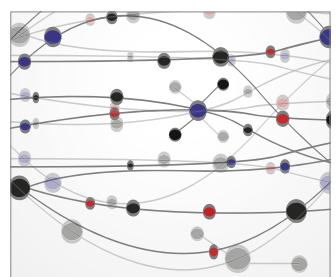

The Scientific World Journal
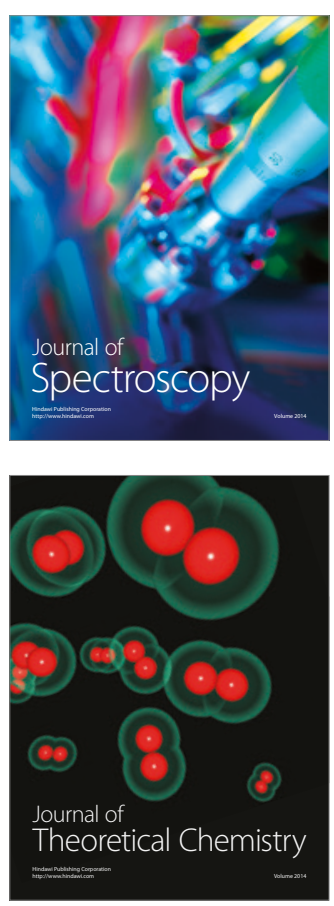
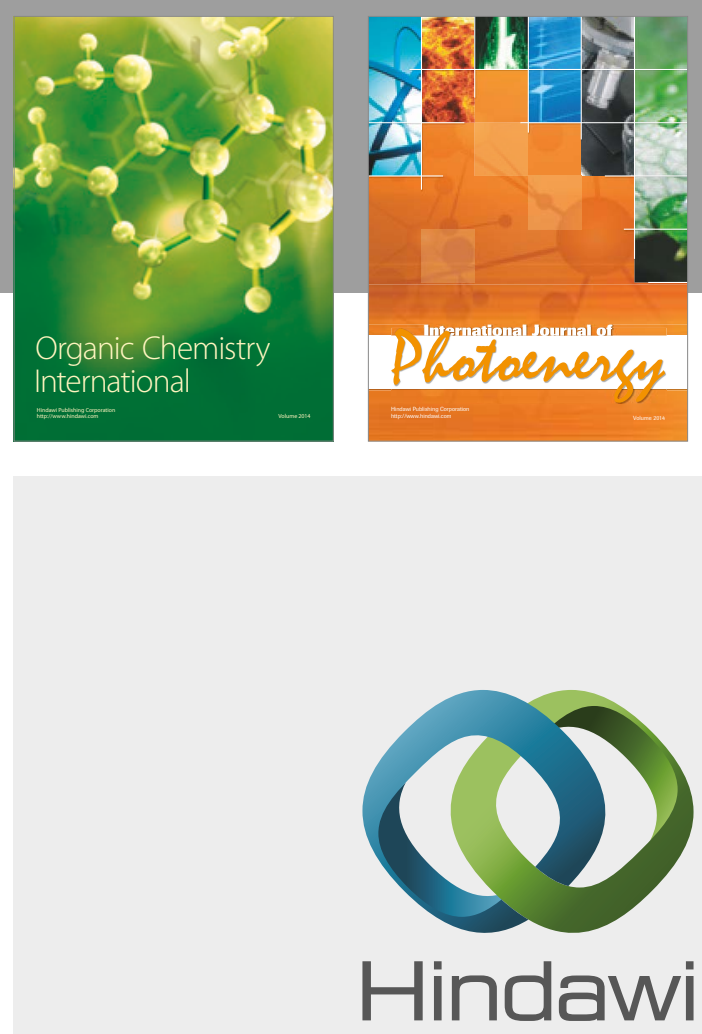

Submit your manuscripts at

https://www.hindawi.com

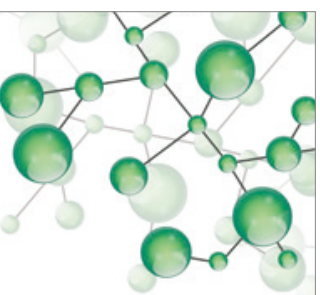

International Journal of

Inorganic Chemistry

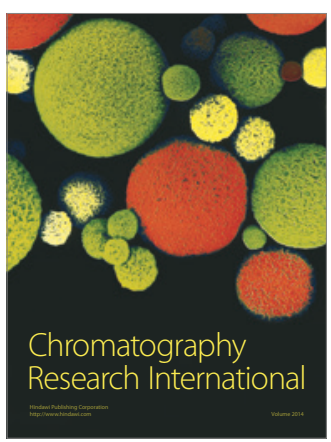

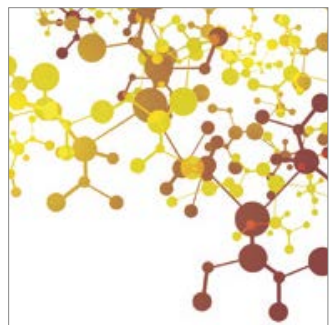

Applied Chemistry
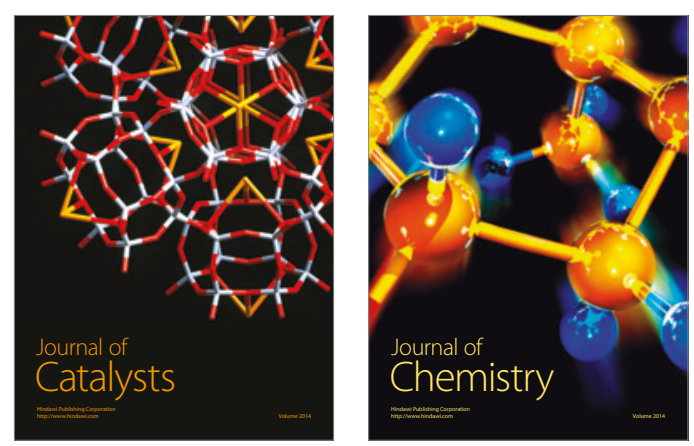
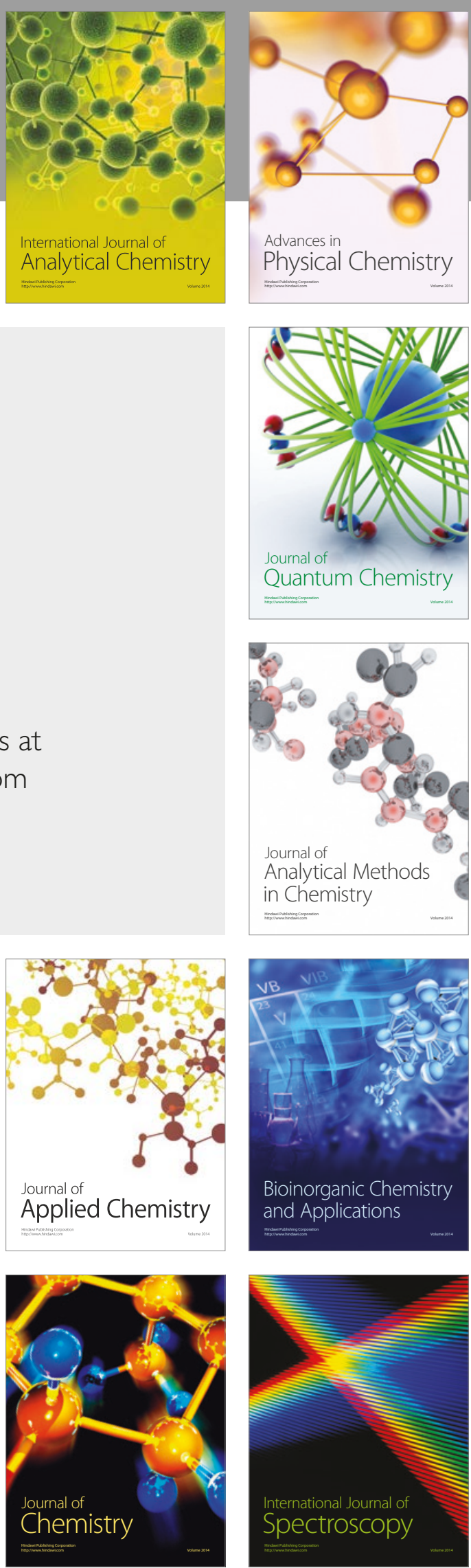